\title{
Akses Kamera CCTV Dari Jarak Jauh Untuk Monitoring Keamanan Dengan Penerapan PSS
}

\author{
Fahlepi Roma Doni \\ Teknologi Komputer, Universitas Bina Sarana Informatika \\ Indonesia \\ Email :fahlepi.fro@bsi.ac.id
}

\begin{abstract}
With the increasingly rapid development of information technology at this time, the development of technology in the field of security also develops, with the presence of devices and applications for monitoring security. The higher cases of crime or crime as well as the level of busyness of the community itself, we need a security or monitoring to overcome the criminal world itself. In this case the researchers continue to develop CCTV camera technology. This CCTV camera is increasingly used by the public at large. So campuses, government agencies or companies in general need monitoring or monitoring the situation to improve security. The technology is used so that we can monitor or monitor the situation and condition of different places or regions by using a CCTV monitoring application, by using this application, it is as if we will be in one place in front of us, the scope that we can monitor is not limited area, different places, islands, countries and even different continents can monitor each other, it can even become a global scope (the world), i.e. using computer networks that are connected to the internet, to use devices that are already connected to computer networks from different areas, can be affordable with CCTV monitoring applications. With the implementation of PSS (Pro Surveillance System) monitoring it can even reach a wider area, so CCTV monitoring can be accessed whenever and wherever we are.
\end{abstract}

Keywords : Information Technology; CCTV Monitoring; PSS.

Abstrak - Dengan semakin majunya perkembangan teknologi informasi saat ini, maka perkembangan teknologi dibidang keamanan juga ikut berkembang, dengan adanya prangkat dan aplikasi untuk memantau keamanan. Semakin tingginya kasus tindak kejahatan atau kriminal serta tingkat kesibukan masyarakat itu sendiri maka dibutuhkan suatu keamanan atau monitoring untuk mengatasi dunia kriminal itu sendiri. Dalam hal ini para peneliti terus berupaya mengembangkan tekhnologi kamera CCTV. Kamera CCTV ini semakin pesat digunakan oleh masyarakat pada umumnya. Maka kampus-kampus, instansi pemerintahan atau perusahaan pada umumnya memerlukankan monitoring atau pemantauan situasi untuk meningkatkan keamaannya. Teknologi yang digunakan supaya kita bisa memonitoring atau memantau situasi dan keadaan tempat atau wilayah yang berbeda dengan menggunakan sebuah aplikasi monitoring CCTV, dengan menggunakan aplikasi ini maka kita seolah-olah akan berada dalan satu tempat yang berada dihadapan kita, cakupan yang dapat kita monitoring itu tidak terbatas wilayah, berbeda tempat, pulau, negara bahkan yang berbeda benua bisa saling memantau, bahkan bisa menjadi cakupan global (dunia), yakni menggunakan jaringan komputer yang sudah terhubung internet, untuk menggunakan perangkat yang sudah terhubung dengan jaringan komputer dari area yang berbeda tempat, bisa terjangkau dengan aplikasi monitoring CCTV. Dengan penerapan monitoring PSS (Pro Surveillance System) ini bahkan bisa menjangkau wilayah yang lebih luas, jadi monitoring CCTV bisa diakses kapan pun dan dimana pun kita berada. 
Kata kunci : Teknologi Informasi ; Monitoring CCTV; PSS.

\section{PENDAHULUAN}

\section{CCTV (Closed Circuit Television)}

sudah menjadi alat pengawasan yang umum dipakai pada era sekarang ini, namun pengawasannya harus dilakukan dengan menggunakan perangkat yang bisa dipantau dengan komputer. Hal ini akan mengurangi tingkat pengawasan dikarenakan personal komputer membatasi ruang lingkup pengawas, sedangkan kebutuhan pengawas untuk melakukan mobilitas terkadang sulit dihindari. Maka aplikasi untuk memantau CCTV akan sangat berguna untuk pemantauan situasi.

Pada Kampus Universitas Bina Sarana Informatika sudah memiliki infrastruktur jaringan komputer untuk memenuhi kebutuhan akses internet baik untuk karyawan, staf pengajar, maupun untuk mahasiswa. Oleh karna itu penulis tertarik untuk menganalisa dan menerapkan aplikasi monitoring CCTV dengan penerapan aplikasi monitoring PSS (Pro Surveillance System). Penelitian penerapan yang dilakukan bertujuan untuk meningkatkan keamanan yang lebih baik lagi studi kasus pada Kampus UBSI Tangerang.

Implementasi yang dibuat ini nantinya berguna untuk melihat keadaan ruangan atau tempat -tempat tertentu dan bisa dipantau langsung menggunakan perangkat mobile device Android atau dari Laptop/PC/Tablet dan lain-lain. Jadi situasi keadaan sekitar tetap bisa terpantau oleh aplikasi monitoring yang sudah ter-install tersebut asalkan terdapat koneksi internet yang memadai seperti $W i-f i$ atau layanan paket data operator seluler yang sama. Hasil anlisis dari penerapan aplikasi kamera CCTV yang dapat mempermudah dalam pengontrolan monitoring CCTV .

Dengan menerapkan pengawasan menggunakan monitoring CCTV maka keamanan ruangan dapat terjaga dengan baik. Berdasarkan uraian dari latar belakang di atas, maka penulis akan berfokus pada bagaimana "Implementasi kamera CCTV", diharapkan mampu menangani permasalahan yang telah diuraikan di atas.

Penelitian penerapan ini dilakukan bertujuan untuk :

a. Penggunaan aplikasi monitoring CCTV untuk jaringan komputer dari area atau wilayah yang berbeda, juga bisa kita kendalikan melalui aplikasi monitoring CCTV, jadi tidak terbatas menggunakan jaringan local saja.

b. Untuk mengetahui penyebab atau faktor apa saja yang mempengaruhi penggunaan aplikasi monitoring CCTV.

c. Untuk mengetahui bagaimana model atau metode penggunaan aplikasi monitoring CCTV. 
d. Memberikan saran atau masukan untuk pengguna aplikasi monitoring CCTV.

\section{BAHAN DAN METODE}

\subsection{Bahan}

\section{A. Pengertian Aplikasi Monitoring}

(Bestari, 2016) aplikasi adalah penggunaan program pada komputer, instruksi (instructiom) atau pernyataan (statement) yang disusun sedemikian rupa sehingga komputer dapat memproses input menjadi output atau aplikasi adalah suatu program komputer yang dibuat untuk mengerjakan dan melaksanakan tugas khusus dari pengguna.

(Sutoyo, Triyono, \& Saepudin, 2017) Pemantauan jarak jauh atau Monitoring adalah pemantauan secara terus menerus terhadap fungsi kegiatan-kegiatan didalam hal jadwal penggunaan input / masukan data oleh kelompok sasaran berkaitan dengan harapan-harapan yang telah direncanakan.

\section{B. Pengertian CCTV}

(Rakhmadhani, Wibowo, \& Gunawan, 2008) CCTV (Closed Circuit Television) adalah alat perekaman yang menggunakan satu atau lebih kamera video dan menghasilkan data video atau audio. CCTV adalah penggunaan video kamera yang mentransmisikan sinyal atau penyiaran tertuju kepada lingkup perangkat tertentu, yakni seperangkat monitor "spesifik terbatas".

\section{Akses jaringan CCTV jarak jauh}

(Astra \& Mardiana, 2018) Akses jaringan komputer jarak jauh sering dianggap melakukan tindakan illegal. Karena banyak disalah gunakan untuk proses pencurian data, merusak system dan sebagainya.

(Astra \& Mardiana, 2018) adapun fungsi jaringan komputer jarak jauh yang bersifat Global.

a. Mengendalikan PC atau perangkat dari lokasi berbeda.

b. Mematikan PC atau perangkat dari tempat yang berbeda

c. Mengawasi penggunaan PC atau perangkat lain

d. Mengawasi penggunaan PC atau perangkat lain

e. Pemeliharaan $\mathrm{PC}$ atau perangkat lain

D. Jaringan Komputer dan Topologi

(Kadir \& Triwahyuni, 2013) "Jaringan komputer adalah kumpulan komputer suatu kesatuan system".

(Soepomo, 2014) “Topologi dalam jaringan mengandung dua pengertian dilihat dari sisi pengkabelan dan dari sisi aliran data".

(Wonkar, Sinsuw, \& Najian, 2015) internet adalah gabungan dari berbagai LAN dan WAN yang berada diseluruh dunia secara global.

\section{E. Perencanaan Penerapan}


(Triyono \& Dharma, 2018) menyarankan langkah-langkah dalam sebuah perencanaan penerapan meliputi : Mengidentifikasi masalah, merumuskan masalah, menganalisis masalah dan merumuskan tindakan, membuat rencana, melaksanakan tindakan, mengamatinya, mengolah, menafsirkan data penerapan, dan melaporkan hasil penerapan.

(Stringer, 2007) Meskipun demikian ada beberapa tahapan bisa dilalui dalam penerapan yaitu : tahap perencanaan, tahap pelaksanaan, pengamatan (observation), dan refleksi (reflection).

(Stringer, 2007) Kemudian keempat langkah tersebut dikemukakan oleh Lewin diatas, oleh Stringer : Perencanaan (planning), Pelaksanaan (implementing) dan Penilaian (evaluation)

\subsection{METODE}

Dalam penelitian penerapan ini dilakukan empat tahapan proses yang dilakukan di kampus UBSI Tangerang sebagai tempat studi kasus, keempat tahapan ini dilakukan secara berurutan dan berkaitan antara tahapan satu dengan tahapan yang lain :

\section{A. Pencarian data}

Pencarian data dilakukan dengan 3 proses yang pertama Mengamati situasi atau kondisi yang ada di kampus UBSI Tangerang. Selanjutnya merancang sistem monitoring keamanan yang baik. Proses yang kedua adalah degan wawancara Adapun proses wawancara berkaitan dengan rancangan monitoring di kampus, agar proses analisis monitoring sesuai dengan tujuan. yang terakhir mengunakan metode kepustakaan yaitu dengan mencari referensi dari sumber bacaan.

\section{B. Analisis}

Analisis dilakukan untuk melihat rancangan monitoring situasi yang ada saat ini. Dalam analisis ini akan dilihat bentuk topologi yang digunakan dan kebiijakan atau pengaturan yang dilakuan pada monitoring.

\section{Perancangan}

Perancangan monitoring CCTV dilakukan dengan hasil dari analisis yang dilakukan ditahapan sebelumnya. Perancangan ini menghasilkan skema yang cocok untuk monitoring yang akan diterapakan apakah hannya pada ruang tertentu atau keseluruhan ruangan yang ada.

\section{Pengujian}

Tahap pengujian dilakukan setelah perancangan berhasil dilakukan pengujian terhadap sistem monitoring yang sudah dilakukan. Pengujian meliputi pengujian keberhasilan sistem utama dimana monitoring sendiri akan berhasil jika pengujian yang lain berkaitan dengan terciptanya keamanan di kampus. 


\section{HASIL DAN DISKUSI}

\subsection{Hasil}

Berdasarkan rancangan yang telah dipaparkan, maka dikembangkan suatu sistem monitoring yang dapat melakukan streaming video dengan media jaringan baik wifi maupun jaringan internet. Pada penelitian penerapan ini penulis mengimplementasi monitoring CCTV pada universitas bina sarana informatika kampus tangerang.

Berdasarkan analisa kalau tidak adanya monitoring dari CCTV dapat mengakibatkan keamanan yang kurang baik dan kerugian materi akibat kurangnya dari keamanan tersebut. Oleh karena itu, penulis menerapkan monitoring CCTV yang bisa diakses dari jarak jauh, baik menggunakan smartphone atau menggunakan komputer, pada penelitian ini penulis akan fokus monitoring CCTV dengan menggunakan komputer.

Gambar 1 berikut ini merupakan topologi penelitian yang akan penulis terapkan.

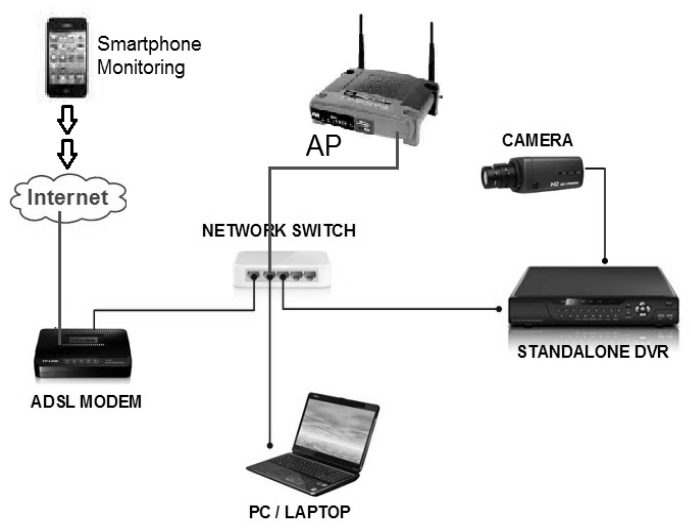

\section{Gambar 1. Topologi penelitian yang} diterapkan

Tahapan-tahapan untuk iplementasi yang penulis gunakan sebagaimana tampak pada gambar 2 .

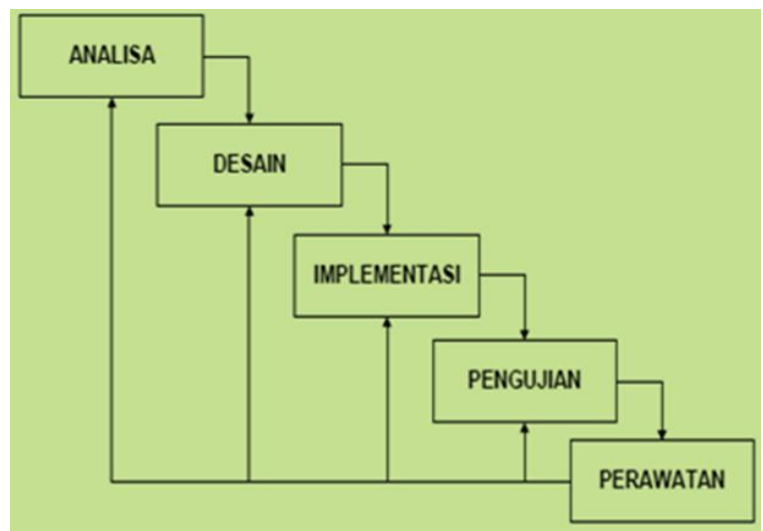

Gambar 2. Tahapan-tahapan untuk penerapan

\section{Konfigurasi Monitoring Keamanan} Dengan Penerapan PSS (Pro Surveillance

\section{System)}

Cara instal PSS aplikasi monitoring CCTV :

a. Jalankan setup aplikasi PSS

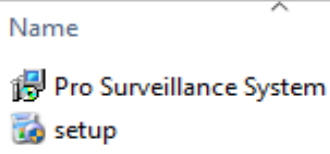

\section{Gambar 3. Setup aplikasi}

b. Kemudian akan tampil gambar seperti ini Klik next untuk menginstal

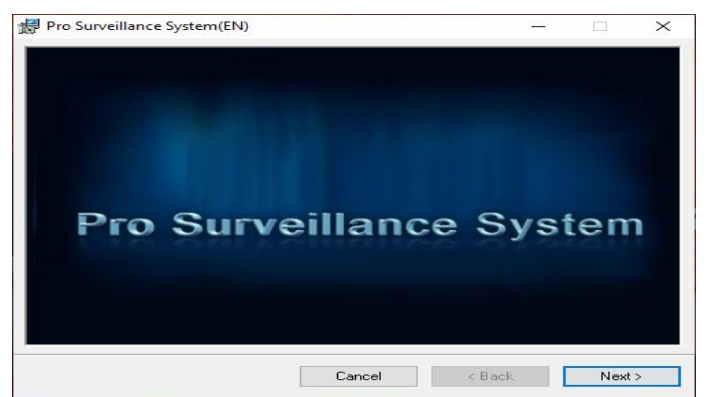

Gambar 4. Proses awal instalasi 
c. Kalau proses instalasi selesai maka akan tampil seperti gambar dibawah ini

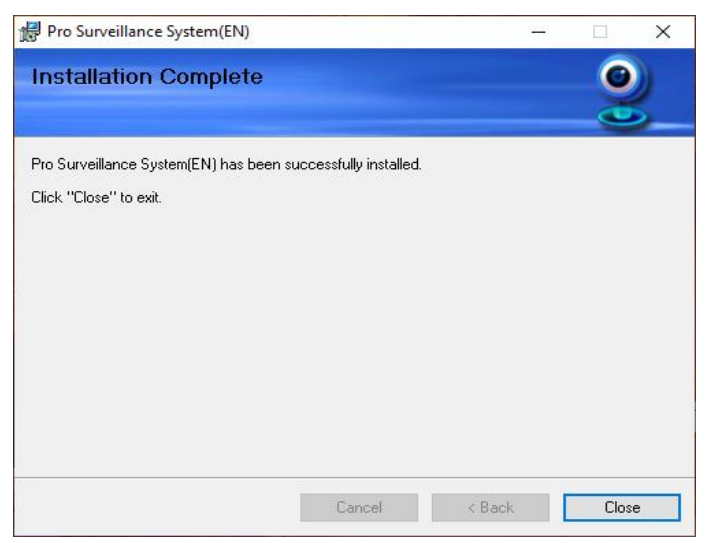

Gambar 5. . Proses instalasi

Pengujian aplikasi PSS (Pro Surveillance System)

a. Setelah itu login ke aplikasi PSS, Tulis username dan password kemudian klik login, seperti pada gambar berikut ini :

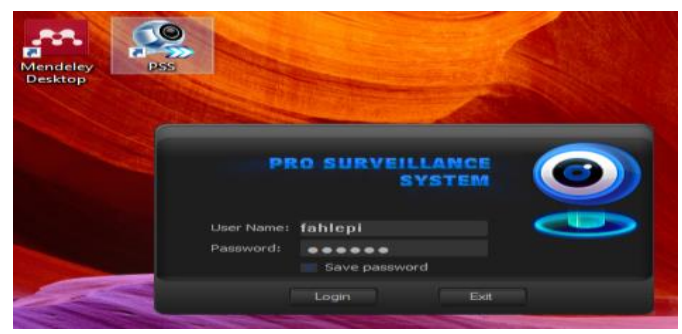

\section{Gambar 6. Login pada aplikasi PSS}

b. Setelah login maka akan tampilan halaman seperti dibawah ini :

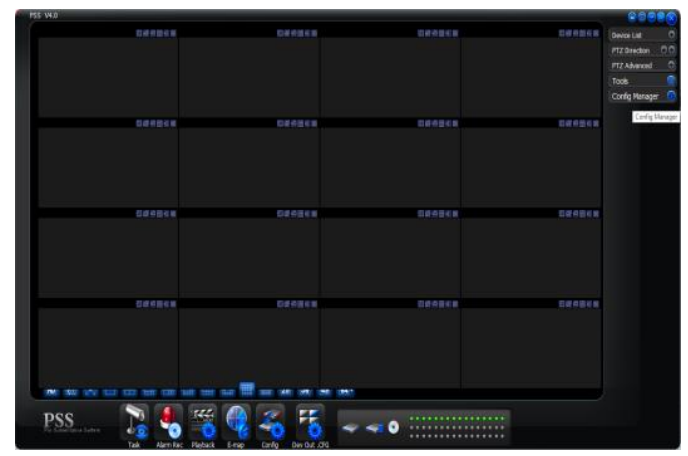

Gambar 7. Halaman utama PSS c. Pilih menu config manager kemudian pilih menu device manager seperti gambar dibawah ini :

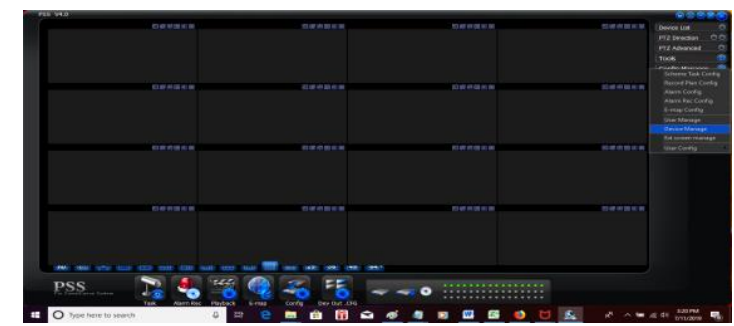

\section{Gambar 8. Halaman utama PSS}

d. Setelah itu akan tampil menu device manager seperti dibawah ini, setelah itu isi title dengan nama Kampus UBSI, tipe pilih DVR, IP tulis IP Address DVR, kemudian masukan username dan password lalu kelik Add dan OK.

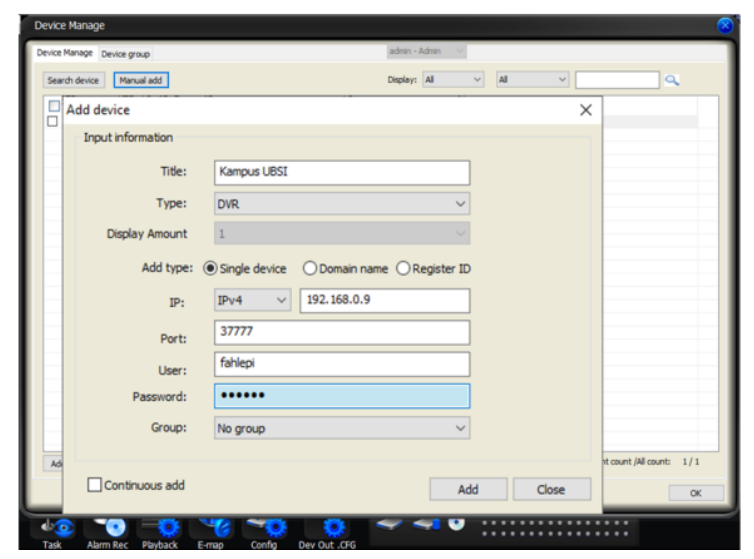

Gambar 9. Input device manager

e. Jika login ke DVR berhasil maka akan muncul pesan succes login seperti gambar dibawah ini :

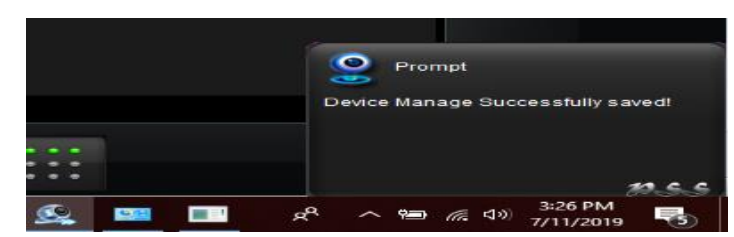




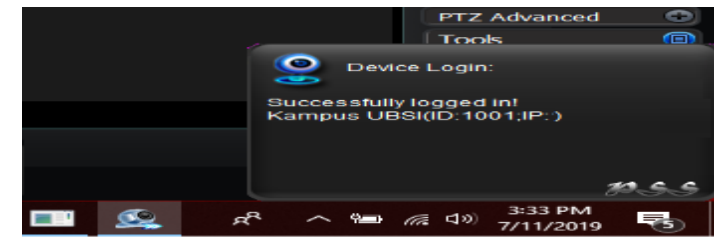

Gambar 10. Pesan sukses konfigurasi awal dan berhasil login pada aplikasi PSS

f. Kemudian klik kanan pada nama divice kamera, lalu pilih main stream untuk menampilkan kamera CCTV yang sedang aktif :

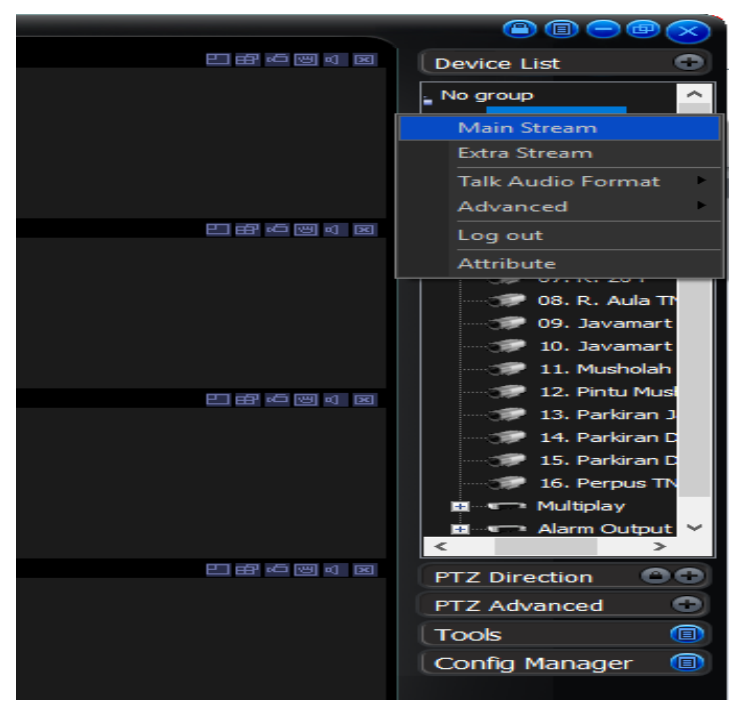

Gambar 11. Menampil kan kamera yang sedang aktif

f. Pada tab menu silahkan pilih berapa kamera CCTV yang hendak ditampilkan 4, 8, dan 16

g.

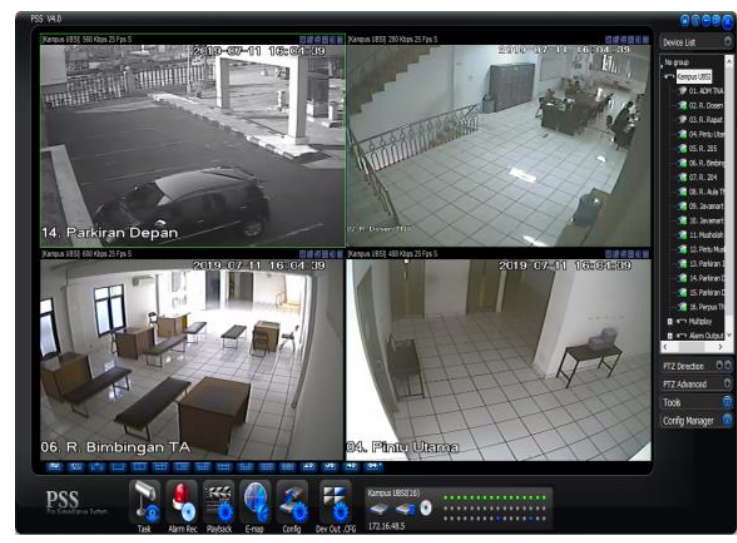

Gambar 12. Tampilan kamera yang aktif

\subsection{Diskusi}

Dari hasil diskusi yang dilakukan terhadap implementasi monitoring CCTV keamanan dengan menggunakan aplikasi PSS (Pro Surveillance System), didapatkan hasil yang cukup memuaskan bagi penggunanya, terutama bagi pihak kampus untuk lebih meningkatkan lagi keamanan lingkungan kampus. Dan mendapatkan juga hasil diskusi tentang :

a. Perawatan sistem monitoring keamanan diperlukan untuk memaksimalkan sistem yang berjalan.

b. Penanganan resiko diperlukan untuk menangani resiko-resiko yang mungkin ada pada saat implemntasi.

c. Pengaturan hak akses diperlukan untuk mengatur batasan-batasan dari pengguna sistem keamanan dilingkungan kampus dan membuat prosedur-prosedur yang berkaitan dengan pengaturan hak akses monitoring CCTV. 
d. Monitoring keamanan menggunakan CCTV diperlukan untuk memantau semua kegiatan yang ada dilingkungan kampus.

\section{KESIMPULAN}

Pada penelitian ini penulis menggunakan aplikasi PSS (Pro Surveillance System) monitoring CCTV adalah untuk membuat atau merancang suatu jaringan cetv yang terhubung pada jaringan komputer yang bisa kita akses darimana saja dan tanpa harus berada atau dating ke lokasi DVR berada.

Setelah penulis melakukan analisa pada penerapan penggunaan aplikasi PSS monitoring CCTV yang terhubung pada jaringan komputer yang bisa diakses darimana, maka dapat disimpulkan :

1. Dari penelitian sebelumnya bahwa pemantauan atau monitoring hanya bisa dilakukan yang sifatnya local area network saja.

2. Kemudian didalam penelitian ini penulis menerapkan penggunaan aplikasi PSS monitoring CCTV untuk bisa diakses dari wilayah yang berbeda, tanpa harus dating ke lokasi DVR berada.

3. Media internet mampu menjadi penghubung DVR yang sudah terhubung pada jaringan komputer jarak jauh, terutama yang dilakukan di area yang berbeda.

4. Dengan memanfaatkan aplikasi PSS monitoring CCTV mampu bekerja sebagai control tau pemantauan dari jarak jauh.

5. Aplikasi PSS monitoring CCTV ada fitur khusus untuk penggunanya sehingga proses terjadinya monitoring dan akses dalam proses pemantauan yang dilakukan.

\section{UCAPAN TERIMA KASIH}

Penelitian ini dapat dilaksanakan dengan baik berkat bantuan dari berbagai pihak, untuk itu peneliti mengucapkan terima kasih yang sebesar-besar kepada semua pihak yang telah banyak membantu dan memberikan kerjasama yang baik dalam penelitian ini, sehingga penilti dapat menyelesaikan penelitian ini tepat waktu.

\section{REFERENSI}

Astra, O. A., \& Mardiana, Y. (2018). Rancang Bangun dan Analisa Pengendali CCTV Berbasis Arduino Menggunakan Smartphone Android. Jurnal Media Infotama, Vol.14 No.(1), 39-50.

https://doi.org/10.1016/j.ecss.2008.01.0 08

Bestari, M. (2016). Rancangan Aplikasi Monitoring Kamera Cctv Untuk Perang' Kat Mobile Berbasis Android. 
Teknologi Informatika Dan Komputer, $3,46$.

IKadir, A., \& Triwahyuni, T. (2013). Pengantar Teknologi Informasi Edisi Revisi (p. 2). $\quad$ p. 2. https://doi.org/10.13140/2.1.4734.7840 Rakhmadhani, D., Wibowo, A., \& Gunawan, H. (2008). Alat Pengaman Ruangan Dengan Closed Circuit Television (Cctv). Alat Pengaman Ruangan Dengan Closed Circuit Television (Cctv), 7(1), 68-78.

Soepomo, P. (2014). 210977-Analisis-DanOptimalisasi-Jaringan-Mengg[1] . 2, 1370-1378.

Stringer, E. (2007). Action Research 3rd. ed. In Action Research.

Sutoyo, Triyono, \& Saepudin. (2017). Penerapan Fitur Kamera CCTV Untuk Access Control System ( ACS ) Menggunakan System Onguard 2013. Seminar Naional Informasi, Komunikasi Dan Industri, 400-407.

Triyono, T., \& Dharma, U. W. (2018). Penelitian Tindakan Kelas: Apa Dan Bagaimana Melaksanakannya? (March), $1-17$. https://doi.org/10.13140/RG.2.2.26385. 12649

Wonkar, S., Sinsuw, A., \& Najian, X. (2015). Analisa Implementasi Jaringan Internet Dengan Menggabungkan Jaringan LAN Dan WLAN Di Desa
Kawangkoan Bawah Wilayah Amurang II. E-Journal Teknik Elektro Dan Komputer, 4(6), 62-68. Retrieved from https://ejournal.unsrat.ac.id/index.php/e lekdankom/article/view/10400/9986 